Int. J. Dev. Biol. 52: 737-742 (2008)

doi: $10.1387 / \mathrm{ijdb} .072538 \mathrm{dc}$

\title{
Participation of cysteine-rich secretory proteins (CRISP) in mammalian sperm-egg interaction
}

\author{
DÉBORA J. COHEN, DOLORES BUSSO, VANINA DA ROS, DIEGO A. ELLERMAN, JULIETA A. MALDERA, \\ NADIA GOLDWEIC and PATRICIA S. CUASNICU* \\ Instituto de Biología y Medicina Experimental (IBYME-CONICET), Buenos Aires, Argentina.
}

\begin{abstract}
Mammalian fertilization is a complex multi-step process mediated by different molecules present on both gametes. CRISP1 (cysteine-rich secretory protein 1) is an epididymal protein thought to participate in gamete fusion through its binding to egg-complementary sites. Structure-function studies using recombinant fragments of CRISP1 as well as synthetic peptides reveal that its egg-binding ability resides in a 12 amino acid region corresponding to an evolutionary conserved motif of the CRISP family, named Signature 2 (S2). Further experiments analyzing both the ability of other CRISP proteins to bind to the rat egg and the amino acid sequence of their S2 regions show that the amino acid sequence of the S2 is needed for CRISP1 to interact with the egg. CRISP1 appears to be involved in the first step of sperm binding to the zona pellucida, identifying a novel role for this protein in fertilization. The observation that sperm testicular CRISP2 is also able to bind to the egg surface suggests a role for this protein in gamete fusion. Subsequent experiments confirmed the participation of CRISP2 in this step of fertilization and revealed that CRISP1 and CRISP2 interact with common egg surface binding sites. Together, these results suggest a functional cooperation between CRISP1 and CRISP2 to ensure the success of fertilization. These observations contribute to a better understanding of the molecular mechanisms underlying mammalian fertilization.
\end{abstract}

KEY WORDS: gamete, oocyte, fertilization, capacitation, fusion

\section{Introduction}

Fertilization in mammals is a complex process that requires the successful completion of a series of orchestrated steps. Although sperm released from the testis are fully differentiated cells, they are not capable of fertilizing an egg. To become competent to fertilize, sperm must undergo several physiological changes during their transit through the male and female reproductive tracts, known as epididymal maturation and capacitation (Yanagimachi, 1994). Once in the proximity of the egg, sperm must pass through the cumulus cells that surround the egg, bind to and penetrate the zona pellucida (ZP) and, finally, fuse with the egg plasma membrane. Most of these events involving cell-tomatrix and cell-to-cell interactions are mediated by specific molecules present on both gametes. One of these proteins is rat epididymal protein $\mathrm{DE}$, described by our laboratory more than thirty years ago (Cameo and Blaquier, 1976), and also known as CRISP1 for being the first identified member of the highly conserved Cysteine-RIch Secretory Protein (CRISP) family. CRISP proteins have molecular weights of about $20-30 \mathrm{kDa}$ and are characterized by the presence of sixteen conserved cysteine residues, ten of which are clustered in the $\mathrm{C}$-terminal domain of the molecule. Other members of the family have been identified in different mammalian tissues: CRISP2, synthesized exclusively in developing spermatids in the testes (Hardy etal., 1988; Kasahara et al., 1989), CRISP3, with a wider tissue distribution than the other CRISPs including reproductive (prostate and ovary) and non-reproductive (salivary gland, pancreas, thymus and colon) organs (Haendler et al., 1993; Kjeldsen et al., 1996; Udby et al., 2005), and the more recently described CRISP4, exclusively expressed in the epididymis (Jalkanen et al., 2005; Nolan et al., 2006). Other non-mammalian members of the family are present in the venoms of various snakes, lizards and snails (Milne et al., 2003; Morrissette et al., 1995; Yamazaki and Morita, 2004), and

Abbreviations used in this paper: CRISP, cysteine-rich secretory protein; PR-1, plant pathogenesis-related 1 protein; S2, signature 2; ZP, zona pellucida.

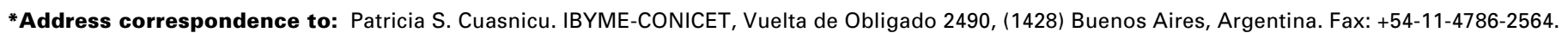
e-mail: cuasnicu@dna.uba.ar
} 
Fig. 1. Schematic representation of the relationship between the behavior and function of rCRISP1. TwO populations of $\mathrm{CR} / \mathrm{SP} 1$ exist on sperm: a loosely bound population, released from sperm during capacitation (CAP) and proposed to act as a decapacitation factor (green dots), and a tightly bound population that remains on sperm after capacitation, migrates to the equatorial segment (ES) with the acrosome reaction $(A R)$, and participates in gamete fusion (pink dots). These biological functions reside in different domains of the protein: the egg binding ability is mediated by the S2 region contained in the PR-1 domain, whereas the potential decapacitation activity might be exerted by the ion-channel regulating activity within the $C R D$.

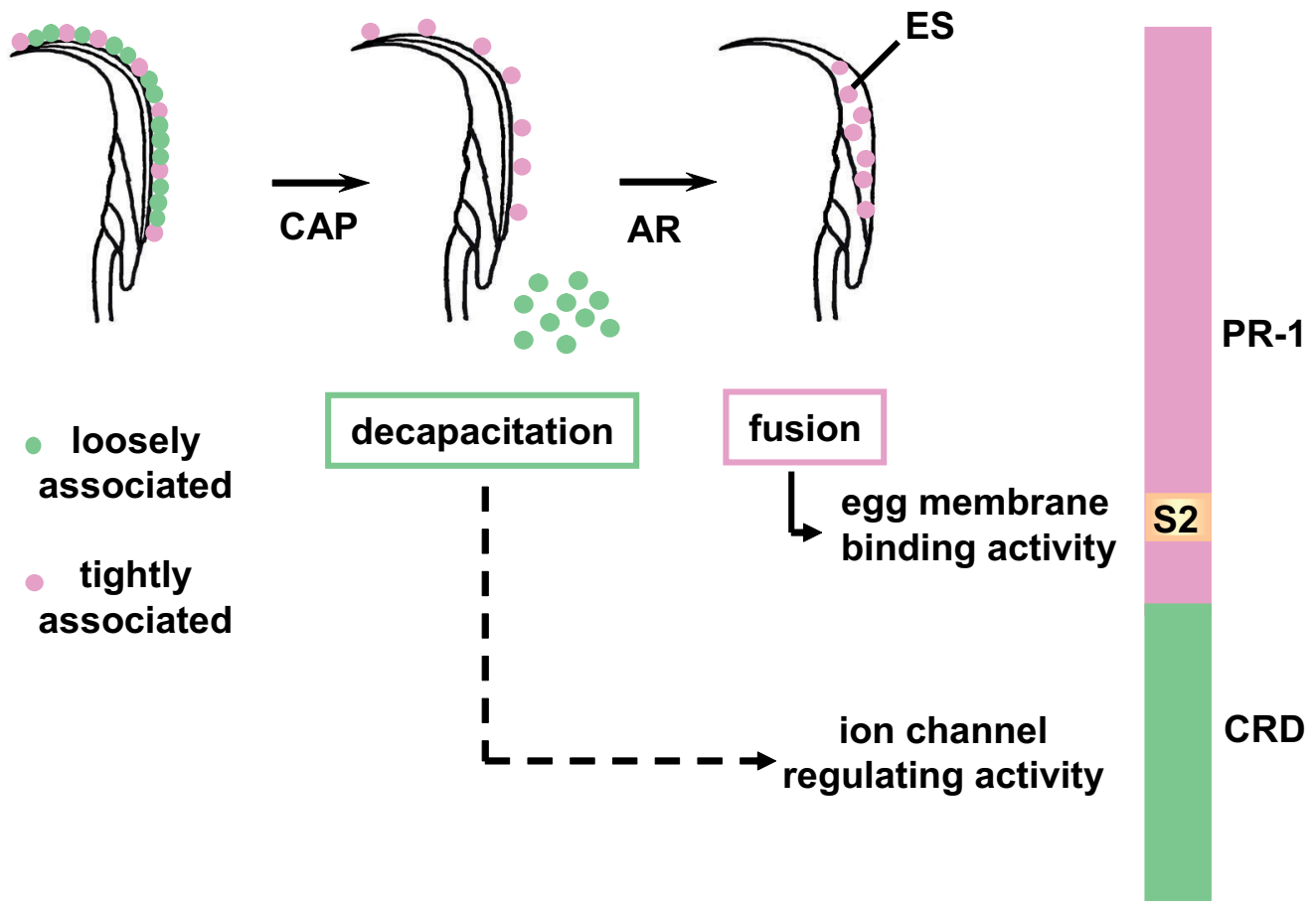

eggs to purified rCRISP1 produced a significant reduction in the percentage of egg penetration without affecting the first step of sperm-egg binding supported the participation of this protein in an event subsequent to binding and leading to fusion (Rochwerger $e t$ al., 1992). These observations also indicated the existence of complementary sites on the egg which were subsequently localized over the entire egg surface with the exception of the area overlying the meiotic spindle, a region through which fusion rarely occurs (Rochwerger et al., 1992). Thus, while rCRISP1 is localized in the fusogenic region of sperm, the corresponding binding sites are localized in the fusogenic region of the egg.

The analysis of the amino acid sequence of rCRISP1 revealed it exhibits a significant $70 \%$ identity with mouse epididymal CRISP1 (Haendler et al., 1993; Mizuki and Kasahara, 1992). Results from our laboratory showed that this homologous protein also participates in sperm-egg fusion through its interaction with complementary sites on the surface of the mouse egg (Cohen et al., 2000a). In humans, a protein with $40 \%$ identity to rCRISP1 has been described (hCRISP1) (Hayashi et al., 1996; Kratzschmar et al., 1996). The absence of a protein more related to rCRISP1 in humans, together with the epididymal origin, molecular weight, and localization of hCRISP1 on the sperm head (Hayashi et al., 1996), led us to investigate its potential participation in human gamete fusion. Results using the hamster oocyte penetration test, showed that incubation of human sperm with an anti-hCRISP1 antibody produced a significant decrease in the sperm ability to penetrate the eggs without affecting any other sperm functional parameter (Cohen et al., 2001). These observations and the presence of binding sites for hCRISP1 on the surface of zona-free human eggs (Cohen et al., 2001), supports the idea that hCRISP1 could be the functional homologue of rCRISP1 in humans.

The results obtained indicated that $\mathrm{rCRISP} 1$ and its functional homologues in both mouse and human participate in gamete fusion through their binding to complementary sites on the egg in sperm- dent associates with the sperm surface during epididymal maturation (Kohane et al., 1980a; Kohane et al., 1980b). Originally localized in the dorsal region of the sperm head, rCRISP1 migrates to the equatorial segment as the acrosome reaction occurs (Rochwerger and Cuasnicu, 1992). The relocation of the protein to the region through which the sperm fuses with the egg (Bedford et al., 1979; in sperm-egg fusion. The finding that exposure of zona-free rat 
surface. However, the molecular mechanisms involved in these interactions remained unknown. Structure-function studies using a recombinant CRISP1 (recCRISP1) protein expressed in a prokaryotic system showed that the activity of the protein does not involve carbohydrates, and resides in the polypeptide region of the molecule (Ellerman et al., 2002). However, rCRISP1 does not present any known functional domain that could explain its involvement in gamete fusion. The evaluation of the biological activity of a series of recombinant fragments of rCRISP1 circumscribed the egg-binding activity of the protein to a region of 45amino acids (114-158) (Ellerman et al., 2006). Interestingly, the analysis of this region revealed it contains the two feature motifs of the CRISP family named Signature 1 (S1) and Signature 2 (S2). To investigate whether these motifs were involved in the egg binding ability of rCRISP1, two synthetic peptides with the amino acid sequence corresponding to each of the motifs were produced (P1 and P2) and examined for their ability to both interact with the egg and inhibit gamete fusion. Results showed that only P2 was capable of binding to the egg and interfering with gamete fusion. The lack of egg labeling and fusion inhibition observed with a peptide containing the same amino acids than $\mathrm{P} 2$ but in a different order (scrambled P2) confirmed the relevance of the S2 region for the binding of rCRISP1 to the egg (Ellerman et al., 2006).

Considering the two structural domains of CRISP proteins, the egg-binding ability of $\mathrm{rCRISP} 1$ resides within the PR-1 domain of the molecule. The involvement of the CRD domain in other potential functions of CRISP1, however, cannot be excluded. Recent evidence indicates that CRISP proteins from snake venoms (Yamazaki and Morita, 2004) as well as mouse CRISP2 (Gibbs et al., 2006), possess an ion-channel regulating activity located in the CRD. In this regard, it is interesting to note that rCRISP1 has been shown to have an inhibitory activity on rat sperm protein tyrosine phosphorylation (Roberts et al., 2003), a capacitation-associated event which depends on the regulation of several ion channels (Visconti et al., 2002). In view of this, it is likely that rCRISP1 acts as a decapacitation factor regulating ion channels through the CRD. These results are in agreement with previous observations from our laboratory revealing the existence of two populations of rCRISP1 bound to sperm: a major (70\%) population loosely associated with sperm by ionic interactions, released from the cells during capacitation, and proposed to act as a decapacitation factor (Cohen et al., 2000b; Kohane et al., $1980 \mathrm{~b})$, and a minor (30\%), tightly bound population that behaves as an integral protein, remains on sperm after capacitation and corresponds to the protein that migrates to the equatorial segment and participates in gamete fusion (Cohen et al., 2000b). According to all these observations, the biological roles of rCRISP1 would not only reside in different domains of the protein but would also be exerted by two different populations (Fig. 1).

The fact that the egg-binding ability of rCRISP1 resides in an evolutionary conserved region of the protein raised the question as to how this common region might possess the necessary specificity for interacting with the different eggs. This was addressed by analyzing the ability of several CRISP proteins to interact with rat eggs in relation to the amino acid sequences of their corresponding S2 regions. While testicular mouse CRISP2 (mCRISP2) was capable of binding to the rat egg, hCRISP1 and helothermine (a CRISP from lizard saliva (Morrissette et al., 1995)) were unable to recognize the rodent gamete. In correlation with this, the $S 2$ region presented only two substitutions in mCRISP2, and four in both hCRISP1 and helothermine, when compared to the S2 in rCRISP1 (Fig. 2). These results suggest that differences within the amino acid sequence of this region may be responsible for the specificity of the binding of each CRISP to its target egg (Ellerman et al., 2006). To our knowledge, these results constitute the first evidence describing a functional role for the motif of the CRISP family and succeeding in delimiting the activity of a CRISP protein to such a small region.

While the findings described above support a role for CRISP1 in gamete fusion, circumstantial observations suggested that this protein might play an additional role in fertilization. The evidence came from in vivo observations showing that rat sperm exposed to a serum against rCRISP1 prior to uterine insemination exhibited a significantly reduced fertilizing ability (Perez Martinez et al., 1995). Interestingly, the non-fertilized eggs did not accumulate sperm in the perivitelline space as expected for the blocking of a protein involved in gamete fusion, suggesting that the antirCRISP1 antibodies might have interfered with an event prior to sperm-egg fusion. In vitro fertilization experiments using zona-

Signature 2 sequence

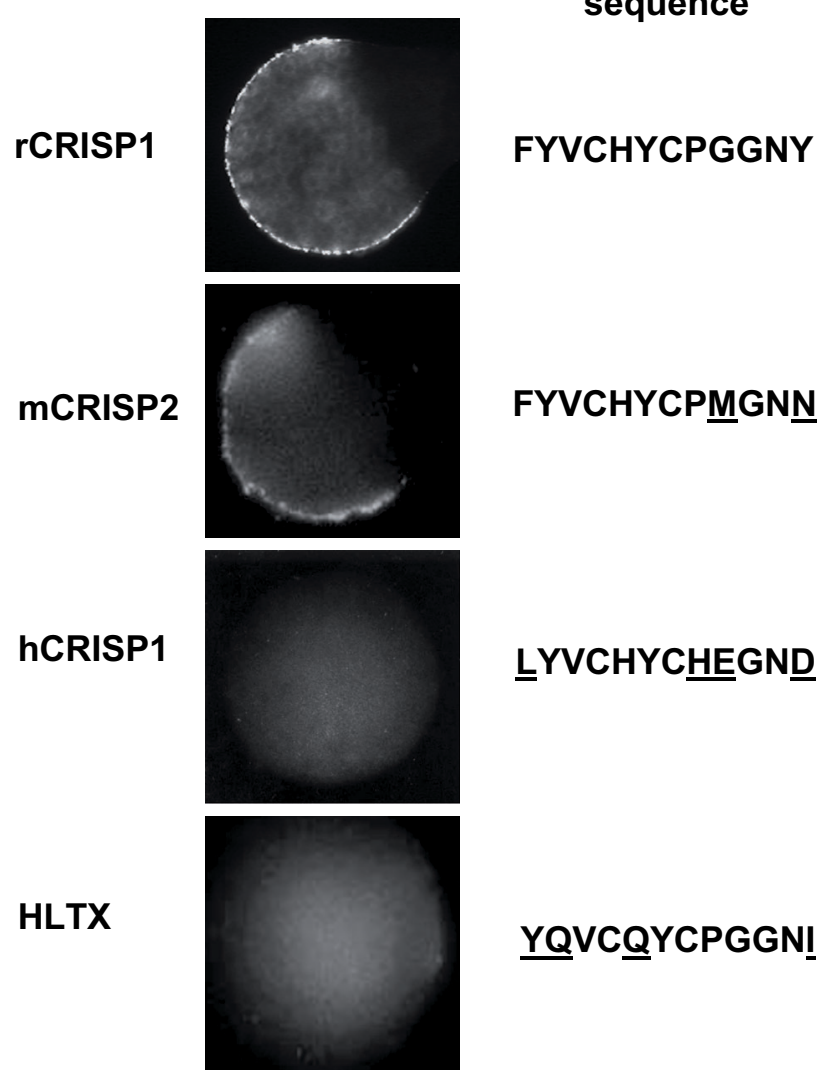

Fig. 2. Egg binding ability of different CRISP proteins. Zona-free rat eggs were incubated with $6 \mu \mathrm{M}$ rCRISP1, mCRISP2, hCRISP1 or helothermine (HLTX), fixed and subjected to indirect immunofluorescence using the corresponding primary antibodies. Note the presence of a fluorescent labeling with a negative area in eggs incubated with rCRISP1 and $m C R I S P 2$. The amino acid sequences of the corresponding S2 regions are shown on the right. The distinct residues between each protein and rCRISP1 are underlined. 
intact rat and mouse eggs revealed that the presence of either an anti-rCRISP1 polyclonal antibody or native rCRISP1 during gamete co-incubation produced a significant decrease in the percentage of fertilized eggs. In all the cases, no perivitelline sperm were observed, suggesting that the inhibitions had occurred at the sperm-ZP interaction level (Busso et al., 2007a). The subsequent evaluation of the effect of anti-rCRISP1 or rCRISP1 on the number of sperm bound per egg indicated that the protein is involved in the initial step of sperm binding to the ZP (Busso et al., 2007a). When recCRISP1 was present during gamete co-incubation, a significant inhibition in egg fertilization was also observed. However, differently to what it was found for the native protein, an increase in the number of perivitelline sperm was observed. In agreement with these results, indirect immunofluorescence experiments revealed that rCRISP1 was capable of binding to both the ZP and the egg plasma membrane, whereas recCRISP1 only bound to the egg surface. The failure of recCRISP1 to interact with the ZP indicated that carbohydrates and/or the protein conformation could be important for the association of rCRISP1 with the ZP. In this regard, the finding that deglycosylated rCRISP1 behaved as the untreated protein while a heat-denatured rCRISP1 associated only with the egg plasma membrane, indicated that the ability of the protein to bind to the ZP depends on the conformation of the protein rather than on its glycosidic moieties (Busso et al., 2007).

Together, the results led us to propose the following model for the participation of CRISP1 during gamete interaction: CRISP1, localized on the dorsal region of capacitated intact sperm, participates in the first step of sperm binding to the ZP probably through a conformation-mediated mechanism. Then, the ZP induces the sperm acrosome reaction which triggers the migration of CRISP1 to the equatorial segment. Once localized in the fusogenic region of the sperm head, CRISP1 mediates gamete fusion through the interaction of its $\mathrm{S} 2$ region with the complementary sites on the egg surface (Busso et al., 2007a).

\section{Testicular CRISP2}

CRISP2 was originally described as one of the primary autoantigens abundantly present within the guinea pig acrosome (Hardy et al., 1988). In rat sperm, CRISP2 was found to exist as a component of the acrosome and the outer dense fibers of the tail (O'Bryan et al., 1998; O'Bryan et al., 2001), and it was recently proposed to play a role as a regulator of calcium influx through ryanodine receptors during capacitation (Gibbs et al., 2006). Other groups reported the localization of CRISP2 on the surface of spermatogenic cells and postulated that the protein could be responsible for the interaction between germ cells and Sertoli cells (Maeda et al., 1998; Maeda et al., 1999). Results from our group showed that in human and mouse sperm, CRISP2 is an intra-acrosomal protein that remains on sperm after the acrosome reaction, opening the possibility for a role of the protein in fertilization. The involvement of CRISP2 in human gamete interaction was evaluated by the hamster oocyte penetration test. The presence of a polyclonal antibody against CRISP2 (anti-CRISP2) during gamete co-incubation produced a significant and dosedependent decrease in the percentage of penetrated zona-free hamster oocytes without affecting sperm motility, the acrosome reaction or sperm binding to the egg plasma membrane (Busso et al., 2005). As another approach to evaluate the participation of

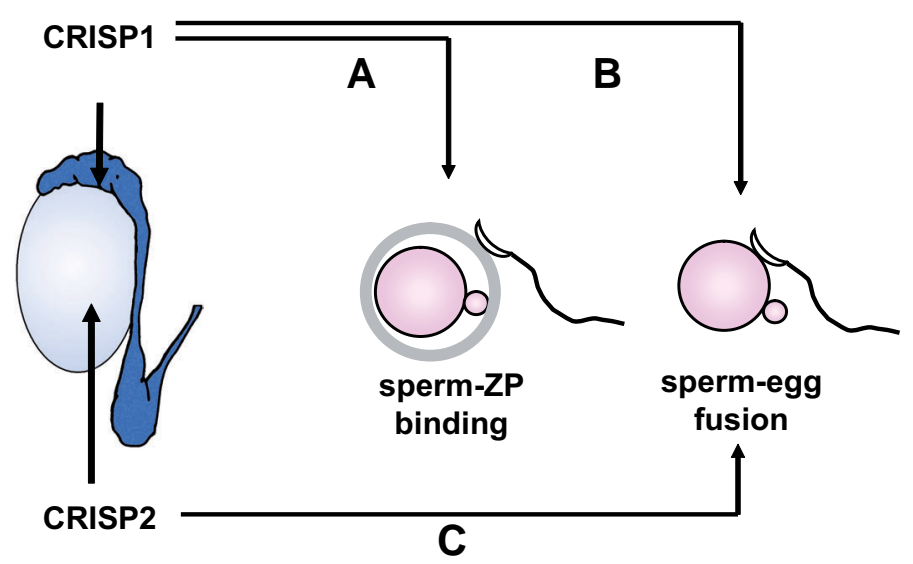

Fig. 3. Schematic representation of the roles of CRISP proteins in different steps of fertilization. Epididymal CRISP1 participates in both sperm-ZP binding (A) and sperm-egg fusion (B). Testicular CRISP2 participates in sperm-egg fusion (C).

human CRISP2 in gamete fusion, the existence of complementary sites for this protein on the surface of human eggs was examined. Immunolocalization studies of zona-free human eggs exposed to bacterially-expressed recombinant CRISP2 (recCRISP2) revealed the presence of specific CRISP2-binding sites on these eggs (unpublished observations). Altogether, these results suggest that CRISP2 participates in human gamete fusion through its interaction with complementary sites on the egg surface. These results, and the finding that mouse CRISP2 was able to bind to the rat egg (see Fig. 2), suggested that CRISP2 could also participate in rodent gamete fusion through egg complementary sites. In agreement with this, the incubation of zona-free rat eggs with different concentrations of recCRISP2 prior to insemination produced a significant and dose-dependent decrease in the percentage of penetrated eggs compared to controls (unpublished observations). The observation that the S2 regions of CRISP1 and CRISP2 differed in only two amino acids suggested that both proteins might interact with the same binding sites on the egg. Indirect immunofluorescence competition studies in which zona-free mouse eggs were exposed to both CRISP1 and CRISP2 confirmed the existence of common egg complementary sites for the two proteins (Busso et al., 2007b). In view of these results, the specific participation of CRISP2 in gamete fusion was studied using the anti-CRISP2 antibody which does not cross-react with CRISP1. Insemination of zona-intact eggs with capacitated sperm in the presence of anti-CRISP2 resulted in a significant decrease in the percentage of fertilized eggs accompanied by an increase in the number of perivitelline sperm per egg (Busso et al., 2007b). These observations indicate an effect of the antibody at the sperm-egg membrane interaction level and support the specific participation of CRISP2 in gamete fusion.

\section{Conclusions}

Increasing evidence indicates the involvement of sperm proteins in more than one step of the fertilization process (Howes et al., 2001; Lin et al., 1994; Primakoff et al., 1985; Shur, 1993; Takano et al., 1993; Talbot et al., 2003). According to our 
observations, CRISP1 would be an example of proteins playing multiple roles during sperm-egg interaction. These results, and the finding that testicular CRISP2 is also involved in sperm-egg fusion, support the idea of different roles for the same CRISP (Fig. $3 A, B)$, and the existence of a functional cooperation between different CRISPs in the same fertilization event (Fig. 3 B,C). Considering that sperm are transcriptionally inactive cells, it is possible that this functional redundancy of proteins in sperm has evolved as a mechanism to ensure the success of the fertilization process.

In summary, our results support the involvement of CRISP proteins in gamete interaction contributing to a better understanding of the molecular mechanisms underlying mammalian fertilization.

\section{Acknowledgements \\ The work described in this review was supported by the World Health Organization (WHO) LID grant (H9/181/R429), the National Research Council (CONICET) grant (PIP 5639), and the National Agency of Scientific and Technological Promotion (ANPCyT) grant (PICT 05-09622) to PSC.}

\section{References}

BEDFORD, J.M., MOORE, H.D.M., and FRANKLIN, L.E. (1979). Significance of the equatorial segment of the acrosome of the spermatozoon in eutherian mammals. Exp. Cell Res. 119:119-126.

BUSSO, D., COHEN, D.J., HAYASHI, M., KASAHARA, M., and CUASNICU, P.S. (2005). Human testicular protein TPX1/CRISP-2: localization in spermatozoa, fate after capacitation and relevance for gamete interaction. Mol.Hum.Reprod. 11:299-305.

BUSSO, D., COHEN, D.J., MALDERA, J.A., DEMATTEIS, A., and CUASNICU, P.S. (2007a). A novel function for CRISP1 in rodent fertilization: Involvement in sperm-zona pellucida interaction. Biol.Reprod. 77:848-854.

BUSSO, D., GOLDWEIC, N.M., HAYASHI, M., KASAHARA, M., and CUASNICU, P.S. (2007b). Evidence for the involvement of testicular protein CRISP2 in mouse sperm-egg fusion. Biol.Reprod. 76:701-708.

CAMEO, M.S. and BLAQUIER, J.A. (1976). Androgen-controlled specific proteins in rat epididymis. J.Endocr. 69:317-324.

COHEN, D.J., ELLERMAN, D.A., and CUASNICÚ, P.S. (2000a). Mammalian sperm-egg fusion: evidence that epididymal protein DE plays a role in mouse gamete fusion. Biol.Reprod. 63:462-468.

COHEN, D.J., ROCHWERGER, L., ELLERMAN, D.A., MORGENFELD, M., BUSSO, D., and CUASNICU, P.S. (2000b). Relationship between the association of rat epididymal protein DE with spermatozoa and the behavior and function of the protein. Mol.Reprod.Dev. 56:180-188.

COHEN, D.J., ELLERMAN, D.A., BUSSO, D., MORGENFELD, M., PIAZZA, A., HAYASHI, M., YOUNG, E.T., KASAHARA, M., and CUASNICU, P.S. (2001). Evidence that human epididymal protein ARP plays a role in gamete fusion through complementary sites on the surface of the human egg. Biol.Reprod. 65:1000-1005, (2001).

ELLERMAN, D.A., COHEN, D.J., DA ROS, V.G., MORGENFELD, M.M., BUSSO, D., and CUASNICU, P.S. (2006). Sperm protein «DE» mediates gamete fusion through an evolutionarily conserved site of the CRISP family. Dev.Biol.297:228237.

ELLERMAN, D.A., DA ROS, V.G., COHEN, D.J., BUSSO, D., MORGENFELD, M.M., and CUASNICU, P.S. (2002). Expression and structure-function analysis of $\mathrm{DE}$, a sperm cysteine-rich secretory protein that mediates gamete fusion. Biol.Reprod. 67:1225-1231.

FERNANDEZ, C., SZYPERSKI, T., BRUYERE, T., RAMAGE, P., MOSINGER, E., and WUTHRICH, K. (1997). NMR solution structure of the pathogenesis-related protein P14a. J.Mol.Biol. 266:576-93.

GIBBS, G.M., SCANLON, M.J., SWARBRICK, J., CURTIS, S., GALLANT, E., DULHUNTY, A.F., and O'BRYAN, M.K. (2006). The cysteine-rich secretory protein domain of $T p x-1$ is related to ion channel toxins and regulates ryanodine receptor $\mathrm{Ca} 2+$ signaling. J.Biol.Chem. 281:4156-4163.

GUO, M., TENG, M., NIU, L., LIU, Q., HUANG, Q., and HAO, Q. (2005). Crystal structure of the cysteine-rich secretory protein stecrisp reveals that the cysteine-rich domain has a K+ channel inhibitor-like fold. J.Biol.Chem. 280:1240512412.

HAENDLER, B., KRATZSCHMAR, J., THEURING, F., and SCHLEUNING, W.D. (1993). Transcripts for cysteine-rich secretory protein-1 (CRISP1; DE/AEG) and the novel related CRISP-3 are expressed under androgen control in the mouse salivary gland. Endocrinology 133:192-198.

HARDY, D.M., HUANG, T.T.F., DRISCOLL, W.J., TUNG, K.S.K., and WILD, G.C. (1988). Purification and characterization of the primary acrosomal autoantigen of guinea pig epididymal spermatozoa. Biol.Reprod. 38:423-437.

HAYASHI, M., FUJIMOTO, S., TAKANO, H., USHIKI, T., ABE, K., ISHIKURA, H., YOSHIDA, M., KIRCHHOFF, C., ISHIBASHI, T., and KASAHARA, M. (1996). Characterization of a human glycoprotein with potential role in sperm-egg fusion: cDNA cloning, immunohistochemical localization, and chromosomal assigment of the gene (AEGL1). Genomics 32:367-374.

HENRIKSEN, A., KING, T.P., MIRZA, O., MONSALVE, R.I., MENO, K., IPSEN, H., LARSEN, J.N., GAJHEDE, M., and SPANGFORT, M.D. (2001). Major venom allergen of yellow jackets, Ves $v 5$ : structural characterization of a pathogenesis-related protein superfamily. Proteins 45:438-448.

HOWES, E., PASCALL, J.C., ENGEL, W., and JONES, R. (2001). Interactions between mouse ZP2 glycoprotein and proacrosin; a mechanism for secondary binding of sperm to the zona pellucida during fertilization. J.Cel/ Sci. 114:41274136.

JALKANEN, J., HUHTANIEMI, I., and POUTANEN, M. (2005). Mouse cysteine-rich secretory protein 4 (CRISP4): a member of the crisp family exclusively expressed in the epididymis in an androgen-dependent manner. Biol.Reprod. 72:1268-1274.

KASAHARA, M., GUTKNECHT, J., BREW, K., SPURR, N., and GOODFELLOW, P.N. (1989). Cloning and mapping of a testis-specific gene with sequence similarity to a sperm-coating glycoprotein gene. Genomics 5:527-534.

KJELDSEN, L., COWLAND, J.B., JOHNSEN, A.H., and BORREGAARD, N. (1996). SGP28, a novel matrix glycoprotein in specific granules of human neutrophils with similarity to a human testis-specific gene product and a rodent spermcoating glycoprotein. FEBS Lett. 380:246-250.

KOHANE, A.C., CAMEO, M.S., PIÑEIRO, L., GARBERI, J.C., and BLAQUIER, J.A. (1980a). Distribution and site of production of specific proteins in the rat epididymis. Biol.Reprod. 23:181-187.

KOHANE, A.C., GONZALEZ ECHEVERRIA, F., PIÑEIRO, L., and BLAQUIER, J.A. (1980b). Interaction of proteins of epididymal origin with spermatozoa. Biol. Reprod. 23:737-742.

KRATZSCHMAR, J., HAENDLER, B., EBERSPAECHER, U., ROOSTERMAN, D., DONNER, P., and SCHLEUNING, W.D. (1996). The human cysteine-rich secretory protein (CRISP) family. Primary structure and tissue distribution of CRISP-1, CRISP-2 and CRISP-3. Eur.J.Biochem. 236:827-836.

LIN, Y., MAHAN, K., LATHROP, W.F., MYLES, D.G., and PRIMAKOFF, P. (1994). A hyaluronidase activity of the sperm plasma membrane protein $\mathrm{PH}-20$ enables sperm to penetrate the cumulus cell layer surrounding the egg. J.Cell Biol. 125:1157-1163.

MAEDA, T., SAKASHITA, M., OHBA, Y., and NAKANISHI, Y. (1998). Molecular cloning of the rat Tpx-1 responsible for the interaction between spermatogenic and Sertoli cells. Biochem.Biophys. Res. Commun. 248:140-146.

MAEDA, T., NISHIDA, J., and NAKANISHI, Y. (1999). Expression pattern, subcelIular localization and structure-function relationship of rat Tpx-1, a spermatogenic cell adhesion molecule responsible for association with Sertoli cells. Dev. Growth Differ. 41:715-722.

MILNE, T.J., ABBENANTE, G., TYNDALL, J.D., HALLIDAY, J., and LEWIS, R.J. (2003). Isolation and characterization of a cone snail protease with homology to CRISP proteins of the pathogenesis-related protein superfamily. J.Biol.Chem. 278:31105-31110.

MIZUKI, N. and KASAHARA, M. (1992). Mouse submandibular glands express an androgen-regulated transcript encoding an acidic epididymal glycoprotein-like molecule. Mol.Cell. Endocrinol. 89:25-32.

MORRISSETTE, J., KRATZSCHMAR, J., HAENDLER, B., EL-HAYEK, R., 
MOCHCA-MORALES, J., MARTIN, B.M., JITANDRAKUMAR, R.P., MOSS, R.L., SCHLEUNING, W.D., CORONADO, R., and POSSANI, L.D. (1995). Primary structure and properties of helothermine, a peptide that blocks ryanodine receptors. Biophys.J. 68:2280-2288.

NOLAN, M.A., WU, L., BANG, H.J., JELINSKY, S.A., ROBERTS, K.P., TURNER, T.T., KOPF, G.S., and JOHNSTON, D.S. (2006). Identification of rat cysteinerich secretory protein 4 (Crisp4) as the ortholog to human CRISP1 and mouse Crisp4. Biol.Reprod, 74:984-991.

O'BRYAN, M.K., LOVELAND, K.L., HERSZFELD, D., MCFARLANE, J.R., HEARN, M.T., and DE KRETSER, D.M. (1998). Identification of a rat testis-specific gene encoding a potential rat outer dense fibre protein. Mol. Reprod.Dev. 50:313-322.

O'BRYAN, M.K., SEBIRE, K., MEINHARDT, A., EDGAR, K., KEAH, H., HEARN, M.T., and DE KRETSER, D.M. (2001). Tpx-1 is a component of the outer dense fibers and acosome of rat spermatozoa. Mol.Reprod.Dev. 58:116-125.

OLSON, J.H., XIANG, X., ZIEGERT, T., KITTELSON, A., RAWLS, A., BIEBER, A.L., and CHANDLER, D.E. (2001). Allurin, a 21-kDa sperm chemoattractant from Xenopus egg jelly, is related to mammalian sperm-binding proteins. Proc.Natl.Acad.SCi.U.S.A 98:11205-11210.

PEREZ MARTINEZ, S., CONESA, D., and CUASNICÚ, P.S. (1995). Potential contraceptive use of epididymal proteins: evidence for the participation of specific antibodies against rat epididymal protein DE in male and female fertility inhibition. J.Reprod.Immunol. 29:31-45.

PRIMAKOFF, P., HYATT, H., and MYLES, D.G. (1985). A role for the migrating sperm surface antigen $\mathrm{PH}-20$ in guinea pig sperm binding to the egg zona pellucida. J.Cell Biol. 101:2239-2244.

ROBERTS, K.P., WAMSTAD, J.A., ENSRUD, K.M., and HAMILTON, D.W. (2003). Inhibition of capacitation-associated tyrosine phosphorylation signaling in rat sperm by epididymal protein crisp-1. Biol. Reprod. 69:572-581.

ROCHWERGER, L., COHEN, D.J., and CUASNICÚ, P.S. (1992). Mammalian sperm-egg fusion: The rat egg has complementary sites for a sperm protein that mediates gamete fusion. Developmental Biology 153:83-90.
ROCHWERGER, L. and CUASNICU, P.S. (1992). Redistribution of a rat sperm epididymal glycoprotein after in vivo and in vitro capacitation. Mol.Reprod.Dev. 31:34-41.

SCHAMBONY, A., HEFELE, J.A., GENTZEL, M., WILM, M., and WEDLICH, D. (2003). A homologue of cysteine-rich secretory proteins induces premature degradation of vitelline envelopes and hatching of Xenopus laevis embryos. Mech.Dev. 120:937-948.

SERRANO, R.L., KUHN, A., HENDRICKS, A., HELMS, J.B., SINNING, I., and GROVES, M.R. (2004). Structural analysis of the human Golgi-associated plant pathogenesis related protein GAPR-1 implicates dimerization as a regulatory mechanism. J.Mol.Biol. 339:173-183.

SHUR, B.D. (1993). Glycosyltransferases as cell adhesion molecules. Curr. Opin. Cell Biol. 5:854-863.

TAKANO, H., YANAGIMACHI, R., and URCH, U.A. (1993). Evidence that acrosin activity is important for the development of fusibility of mammalian spermatozoa with the oolemma: inhibitor studies using the golden hamster. Zygote. 1:79-91.

TALBOT, P., SHUR, B.D., and MYLES, D.G. (2003). Cell adhesion and fertilization: steps in oocyte transport, sperm-zona pellucida interactions, and sperm-egg fusion. Biol.Reprod. 68:1-9.

UDBY, L., BJARTELL, A., MALM, J., EGESTEN, A., LUNDWALL, A., COWLAND, J.B., BORREGAARD, N., and KJELDSEN, L. (2005). Characterization and localization of cysteine-rich secretory protein 3 (CRISP-3) in the human male reproductive tract. J.Andro/26:333-342.

VISCONTI, P.E., WESTBROOK, V.A., CHERTIHIN, O., DEMARCO, I., SLEIGHT, S., and DIEKMAN, A.B. (2002). Novel signaling pathways involved in sperm acquisition of fertilizing capacity. J.Reprod.Immunol. 53:133-150.

YAMAZAKI, Y. and MORITA, T. (2004). Structure and function of snake venom cysteine-rich secretory proteins. Toxicon 44:227-231.

YANAGIMACHI, R. (1994). Mammalian Fertilization., In: E. Knobil and J. D. Neill (eds.), The Physiology of Reproduction., pp. 189-317, Raven Press, New York.

\section{Related, previously published Int. J. Dev. Biol. articles}

See our recent Special Issue Developmental Biology in Poland edited by Tarkowski, Maleszewski and Kloc at: http://www.ijdb.ehu.es/web/contents.php?vol=52\&issue=2-3

See our recent Special Issue Ear Development edited by Fernando Giraldez and Bernd Fritzsch at: http://www.ijdb.ehu.es/web/contents.php?vol=51\&issue=6-7

\section{Defective calcium release during in vitro fertilization of maturing oocytes of LT/Sv mice}

Karolina Archacka, Anna Ajduk, Pawel Pomorski, Katarzyna Szczepanska, Marek Maleszewski and Maria A. Ciemerych

Int. J. Dev. Biol. (2008) 52: doi: 10.1387/ijdb.072397ka

Distinct mechanisms underlie sperm-induced and protease-induced oolemma block to sperm penetration.

Sebastian Komorowski, Katarzyna Szczepanska and Marek Maleszewski

Int. J. Dev. Biol. (2003) 47: 65-69

Mammalian oocyte activation: lessons from the sperm and implications for nuclear transfer.

R Alberio, V Zakhartchenko, J Motlik and E Wolf

Int. J. Dev. Biol. (2001) 45: 797-809

\section{Association of egg zona pellucida glycoprotein mZP3 with sperm protein sp56 during fertilization in mice. \\ $\mathrm{N}$ Cohen and P M Wassarman}

Int. J. Dev. Biol. (2001) 45: 569-576

Sperm-egg interaction at fertilization: glycans as recognition signals. F Rosati, A Capone, C D Giovampaola, C Brettoni and R Focarelli Int. J. Dev. Biol. (2000) 44: 609-618
2006 ISI ${ }^{* *}$ Impact Factor $=3.577^{\star *}$

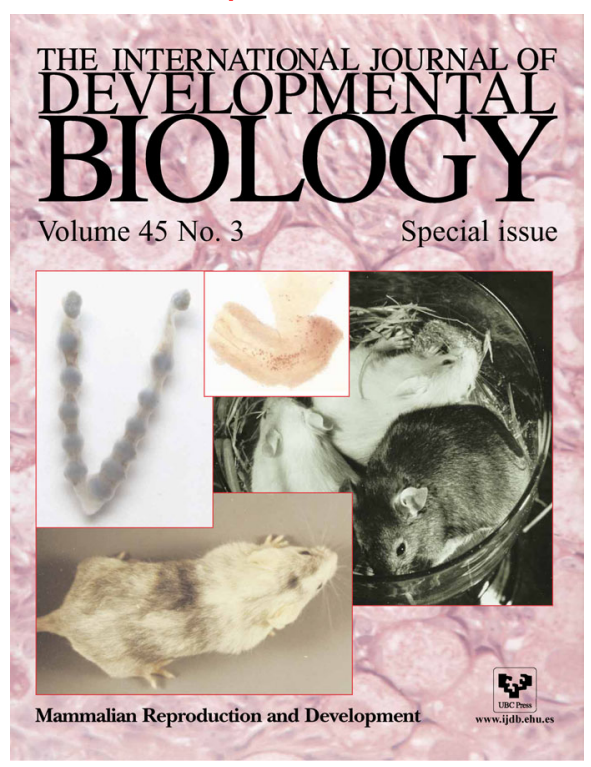

